\title{
Status of Science and Technology Education at Arab High Schools in Israel ${ }^{1}$
}

\author{
By Mahmoud Huleihil ${ }^{*}$ \\ Huriya Huleihil ${ }^{t}$
}

In this study, we provide a review of the status of science and technology education. It addresses the achievements of students in Israel who attend high schools with student bodies that are primarily Arabic speaking. It is generally recognized that the achievements of the Israeli students in international examinations are relatively low. When comparing the achievements of Israeli Arabic speaking students to the achievements of Israeli Hebrew speaking students, there is a low correlation. Some of the questions we try to answer are the following: What are the reasons behind the low scores of Arabic speaking students? Do these low achievement levels affect the future choices of science and technology for those students? Is there a relationship between the science laboratory activities and the bagrut results? (The bagrut-represented by subject-specific certificates is the official Israeli matriculation process that attests to graduation from high school. Receipt by a student of specific bagrut certificates is a prerequisite for higher education in Israel.) Finally, ideas are suggested for improvements (starting at the kindergarten level).

Keywords: achievements, Israeli, school, science, technology

\section{Introduction}

In this study, we focus on the achievements, in Israel, of Arabic speaking high school students in the fields of science subjects, specifically biology, chemistry, and physics. In order to draw a better picture, achievements at elementary, middle, and higher education levels are also considered. The middle school curriculum defines science and technology as a single subject, treating technology as a minor component. In the recent years, science and technology units in middle schools were minimized. These decisions affected students who were continuing toward high school, especially with regards to the likelihood of choosing to concentrate on science or technology subjects. Although the focus in this study is on the narrow issue of science technology, it will be addressed by a general view on education. Based on recent findings, it is a known fact that the achievements of Israeli Arabic speaking students are

\footnotetext{
${ }^{*}$ Senior Lecturer, Beit Berl College, Israel.

${ }^{\dagger}$ Alhozayyel Elementary School, Israel.

${ }^{1}$ The paper is concerned with achievements of Israeli Arab students. The terms Israeli Arab student or Arab students or Arabic speaking or Arabic speaker are used interchangeably. Usually the word pupil is used to reference learners at school up to $12^{\text {th }}$ grade. In this paper the word pupil and the student are used interchangeably. It is written in the text explicitly which group of learners is addressed
} 
lower than the achievements of Israeli Hebrew speaking students of the same age. According to Ben-David Dan (2014), large gaps in achievement still exist between Hebrew and Arabic speakers. As was reported by Jabareen and Agbaria (2010) (who based their findings on the official data published by the Ministry of Education in 2009, with regard to the 2008 Bagrut examinations), results revealed that there is a substantial achievement gap between Hebrew speaking students and Arabic speaking students in Israel. This gap is represented by the rate of matriculation certificates. Hebrew speaking students obtained a 59.74\% success rate; nearly double that of Arabic speaking students, at a success rate of $31.94 \%$. However, a comparison of these figures with those published in previous years reveals a lesser-known fact: the gap between the achievements of Hebrew speaking and Arabic speaking students is not narrowing over time; rather it remains consistent or continues to widen, an important point that was addressed by Jabareen and Agbaria (2010).

In a different study, Ali (2013) addressed the lack of representation of Israeli Arabs in higher education institutes, since its start at the mid-seventies up-to-date. For instance, in the academic year two years ago, the representation of Arabs was in the range 1\% - 10\% in all levels of education and employment, academic or administrative. According to their conclusions, the Ali researchers claimed that the higher the degree the smaller the percentage of Arabs

In their study Wolf and Breit (2012) and Wolf (2014), found that although the achievements of Israeli students on international examinations is relatively low, Israel ranks third in the world in the number of academic degrees per capita (28\% of the population); while Arabs still lag in higher education attendance, especially in science and technology. The researchers commented that while over time, the gaps between Hebrew speaking and Arabic speaking students have declined [contrary to findings of Jabareen and Agbaria (2010)]; they remain significant, with Bedouins in the South being the lowest scorers Wolf (2014). At a recent conference concerning the achievements of Arabs, it was found that Israeli Arabs make up approximately $20 \%$ of Israel's population and $26 \%$ of the relevant age cohort for higher education (Shaviv, Binstein, Stone, \& Fudem, 2013). However, their participation in the higher education system is significantly lower, at about $12 \%$. With each additional level of education, the participation rate declines. These findings agree with the findings in Ali (2013). According to Idit and Dana (2013), a relatively new study, has focused its concern on science education in the secondary schools of Israel. This study shows a pessimistic picture of the status of science and technology in Israel, especially when achievements of the students are compared to those in developed countries. The study reports that the gaps in science and technology education between Israeli Arabic speaking students and Israeli Hebrew speaking students are narrower than those in other levels. However, after high school, the gap widens again. This local improvement in the achievements of Arabic speaking students turns to be negligible if one looks at the academic studies they pursue or the jobs they occupy. The study focuses on the challenges students are 
overcoming, the issue of the lower achievement of Arabic speaking students at all levels of education, and the gap that is even wider when these students leave the academy and seek a job.

In this review the data were collected from published papers and reports addressing education in Israel. It arranges the information in a chronological order from elementary up to higher education. In order to understand the picture of secondary education, we should look at the complete picture. By doing this we keep in mind a few questions: What are the challenges of the Arab education system? How can these challenges be met?

This paper is structured, in the following order. Fistly, the methodology is described, a data collection is given, a summary of the findings regarding high school is given, factors that affect achievements are reviewed, the results and the discussion are given, a summary and the conclusions are put in place and finally certain recommendations are proposed.

\section{Methodology}

The achievements of Israeli Arabic speaking students are described in this review, which is based on comparison to other sectors, i.e., the Israeli Hebrew speaking sector and the OECD countries, as depicted in the following diagram: Three educational systems are described schematically in Figure 1: OECD, Hebrew speaking, and Arabic speaking systems. Blue lines represent the potential linkage between the different systems, hinting at the possibility of interaction and collaboration.

Figure 1. Block Diagram Modeling Three Educational Systems

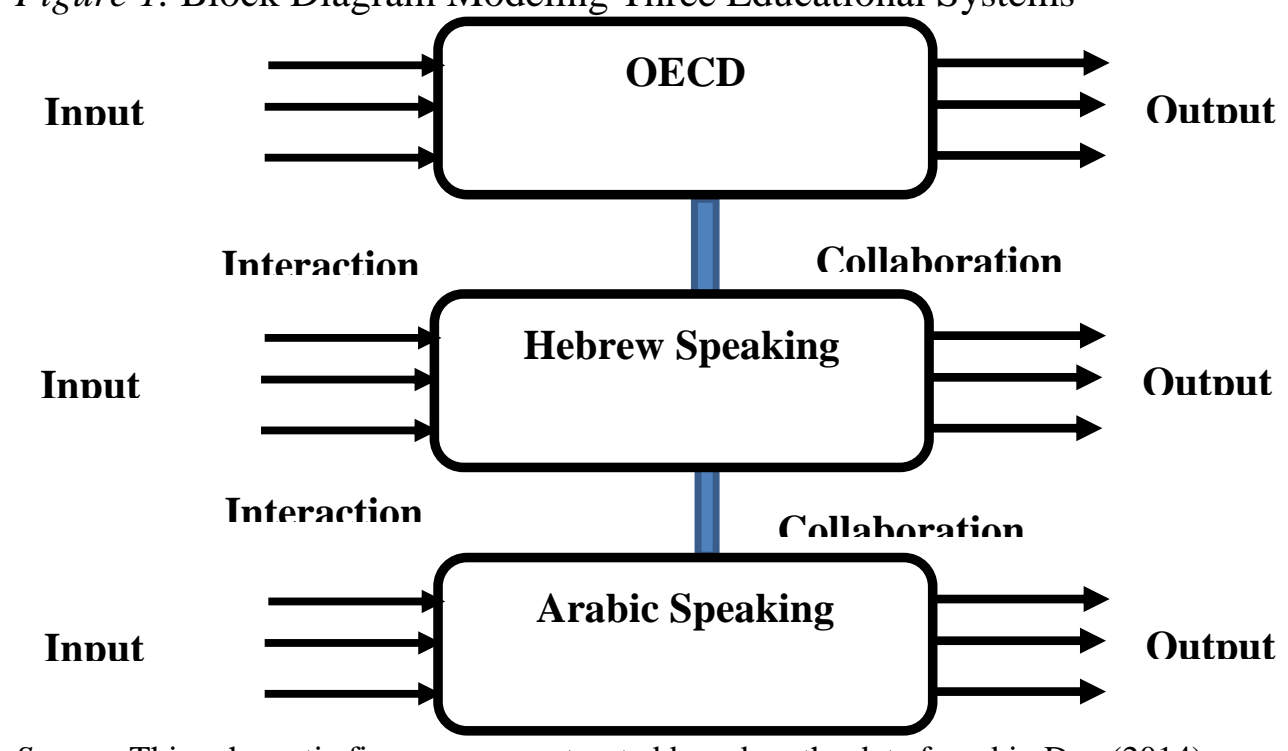

Source: This schematic figure was constructed based on the data found in Dan (2014).

For comparison, two models were created to help study the achievements of the educational systems-detailed modeling (first type) and global modeling 
(second type). The first model type requires detailed knowledge about several items in the system: inputs, initial states, the characteristics of the components of the system, relations between the components, and the driving forces and constraints of the model, itself. This type of modeling is difficult to apply due to the nonlinear nature of the system.

In the second type of modeling, the achievements of students in the different systems are compared, the factors that affect achievements are summarized, conclusions are drawn, and ideas for improvements are suggested.

The data in this review is based on articles and reports [1-32]. These data include information about the population and achievements based on national and international examinations; reasons to explain the state of matters are extracted.

In order to check the effect of the quality of teachers on student achievements, we prepared a questionnaire for teachers using Google drive's form. The questionnaire included items about the education of teachers, their experience in the particular system, levels of bagrut examinations they prepare for with their students, number of science laboratory hours they supervise, grades of bagrut examinations in three, four, and five "bagrut" units ${ }^{2}$ (FBU). The questionnaire was distributed among teachers with the aid of the Inspector of science and technology, who supplied to us a list of their e-mail addresses. Unfortunately, for reasons that are not clear to our sight, the teachers did not cooperate, with less than $3 \%$ responding to the questionnaire. Practically speaking, we learned that inducements, to a degree not yet determined, should be offered to potential survey participants, in order to increase the number of valid responses.

Under this situation, data were collected from articles and reports found in the relevant literature.

\section{Data Collection}

\section{Relative Status of Education Systems - Main Findings}

Based on the published data the main findings are summarized as follows:

1. At the elementary and middle age school levels:

a. The achievements of the OECD countries (Dan, 2014) are higher than the achievements of the Israeli Hebrew speaking system.

b. The achievements of the Israeli Arabic speaking students are lower than the achievements of the Israeli Hebrew speaking students (Dan, 2014).

c. The achievements of the Israeli Arabic speaking students in the Meitzav - Hebrew acronym for "Growth and Efficiency

\footnotetext{
${ }^{2}$ In the Israeli education system, students can choose among three possibilities: three, four and five "bagrut" units.
} 
Measures of Schools" (in short - MEITZAV) examinations are lower than the achievements of Israeli Hebrew speaking students (Dan, 2014).

d. The number of hours taught for science and technology subjects is reduced to four to five hours (instead of six). Half of those hours are dedicated to biology. This situation affects the number of students who choose science subjects during high school.

2. At the high school level:

a. The number of high quality science teachers is low, and in the future the number will be lower (Idit \& Dana, 2013).

b. The percentage of Arabic speaking schools that teach science subjects is higher than that in the Hebrew speaking schools.

c. The percentage of Arabic speaking students who study science subjects is lower than the percentage found in the Hebrew speaking sector.

3. At higher education levels: The representation of the Arabic speaking sector is lower than the representation of the Hebrew speaking sector. The findings follow the general rule: the higher the rank, the lower the representation.

In the following subsection, data are shown to support these findings.

\section{Overall Improvements in Basic Education}

Following the low achievements of Israeli students in international exams the ministry of education decided to take an action. In the academic year 20072008, a new tool, the MEITZAV examination (a calibrated measurement tool) was developed and adopted to measure achievements of Israeli students (Dan, 2014). The aforementioned tool was used to test achievements of Israeli students in languages, math and science and technology. Figure 2 demonstrates the use of the MEITZAV examination and its power of comparing different groups (Arabic speaking and Hebrew speaking). As was reported in Dan (2014): "The results indicate improvement since 2008 among both Hebrew speaking and Arabic speaking pupils, with the greatest improvements concentrated among the 5th grade Arabic speakers" (Figure 2). 
Figure 2. Average Annual Change in Meitzav Examination Scores, 2008-2013 (Not Including Haredi Pupils)
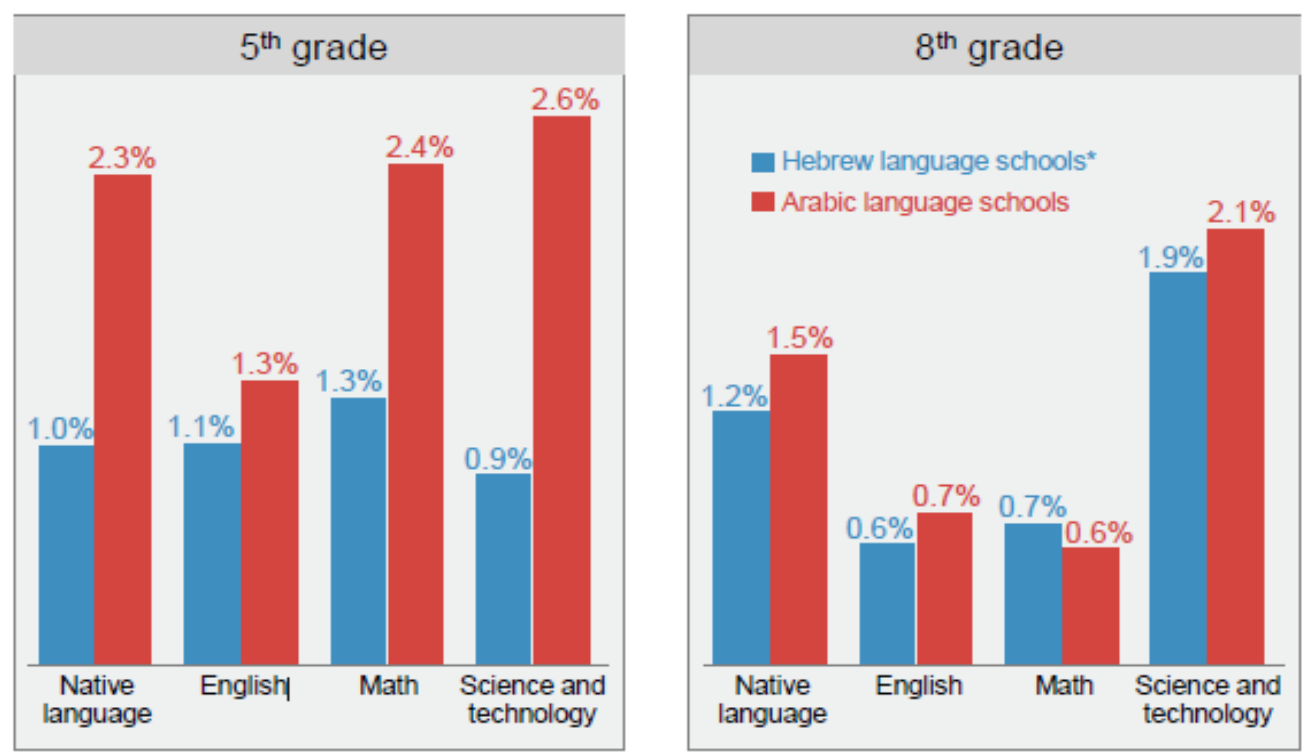

Source: Dan, 2014.

\section{Large Gaps in Achievements between Hebrew and Arabic Speakers}

The relative improvements in educational gains of Israeli students in either system were calculated and compared between the years 2008-2013. Although the gaps are large between hebrew speaking and Arabic speaking students, the Israeli Arabic speaking children exhibited greater gains (see Figure 3) (Dan, 2014).

Figure 3. Gaps Between Hebrew and Arabic Speakers in Meitzav Examinations, 2013 (Not Including Haredi Pupils)

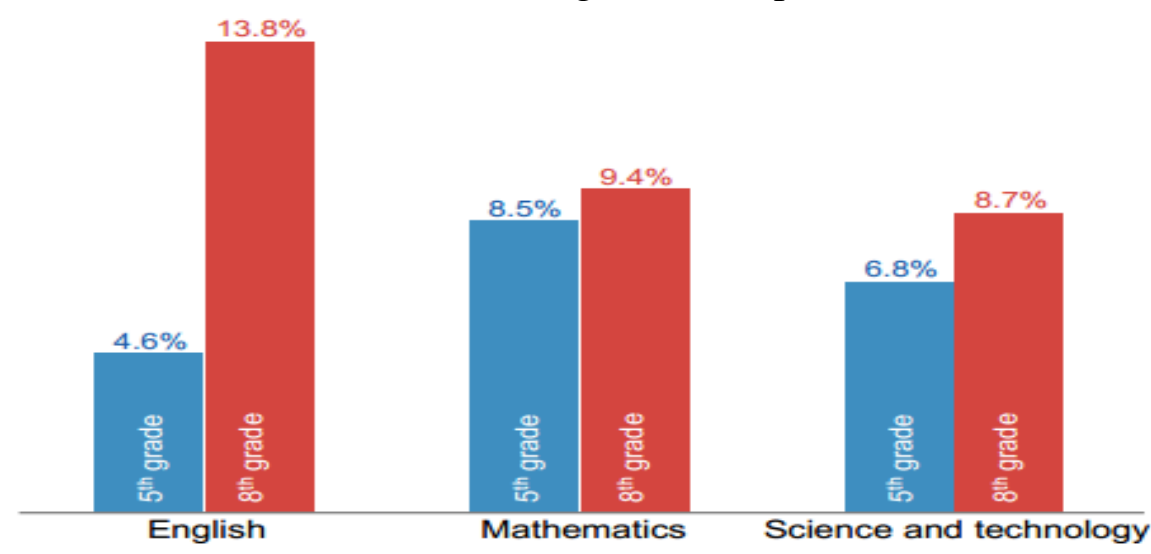

Source: Dan, 2014.

In summary, although there was a greater improvement in achievments of Arabic speakers compared to Hebrew speakers as shown in Figure 1, but still 
the gaps remain large between the groups, particularly in English, showing lower achievments of the Arabic speaking group, as depicted in Figure 2.

\section{Disparities in Education}

Table 1, below, highlights various and significant disparities between education in the Hebrew speaking and Arabic speaking sectors of Israel. Statistical data showed that discrimination against Arab students affects all aspects and levels of education, from preschool up to higher education. These data were collected from official government reports (Jabareen \& Agbaria, 2011).

Table 1. Comparisons between the Arab and Jewish Sectors

\begin{tabular}{|c|c|c|c|}
\hline \multicolumn{2}{|l|}{ Issue } & $\begin{array}{l}\text { Jewish } \\
\text { population }\end{array}$ & $\begin{array}{l}\text { Arab } \\
\text { population }\end{array}$ \\
\hline \multicolumn{2}{|l|}{ Number of children under the age of $17^{\mathrm{II}}$} & $1,699,273$ & 678,000 \\
\hline \multirow{2}{*}{$\begin{array}{l}\text { Average score (approximate) on the } \\
\text { Psychometric Exam, the standardized } \\
\text { exam that is decisive in university } \\
\text { admission (out of } 800)^{\mathrm{XII}}\end{array}$} & Men & 585 & 479 \\
\hline & Women & 548 & 445 \\
\hline \multicolumn{2}{|c|}{$\begin{array}{l}\text { Rate of rejected applicants for university studies } \\
\text { towards a first degree }\end{array}$} & $21.9 \%$ & $38 \%$ \\
\hline \multicolumn{2}{|c|}{$\begin{array}{l}\text { Rate of people aged } 18-39 \text { studying for a first } \\
\text { degree in university. } x \text {. }\end{array}$} & $3.6 \%$ & $1.8 \%$ \\
\hline \multicolumn{2}{|l|}{$\begin{array}{l}\text { Rate of people aged 18-39 studying in any } \\
\text { institute of higher education (colleges and } \\
\text { universities) }\end{array}$} & $7.9 \%$ & $3.9 \%$ \\
\hline \multicolumn{2}{|c|}{$\begin{array}{l}\text { Rate of people aged } 18-39 \text { studying for a second } \\
\text { degree }^{\text {xVI }}\end{array}$} & $1.9 \%$ & $0.5 \%$ \\
\hline \multirow{3}{*}{$\begin{array}{l}\text { Of all university students working } \\
\text { towards first, second or third degrees } \\
\text { (similar to B.A., M.A. and Ph.D), the } \\
\text { percentages of Arabs and Jews are:xvII }\end{array}$} & B.A. & $87.6 \%$ & $13.3 \%$ \\
\hline & M.A. & $93.5 \%$ & $4.9 \%$ \\
\hline & Ph. D & $94.5 \%$ & $2.8 \%$ \\
\hline
\end{tabular}




\begin{tabular}{|c|c|c|}
\hline Issue & $\begin{array}{l}\text { Jewish } \\
\text { population }\end{array}$ & $\begin{array}{l}\text { Arab } \\
\text { population }\end{array}$ \\
\hline Number of children under the age of $17^{\mathrm{II}}$ & $1,699,273$ & 678,000 \\
\hline Rate of daycare registration for two year olds ${ }^{I I I}$ & $61.3 \%$ & $13.7 \%$ \\
\hline $\begin{array}{l}\text { Rate of pre-school registration for three year } \\
\text { olds }^{\mathrm{IV}}\end{array}$ & $87.6 \%$ & $74.9 \%$ \\
\hline Rate of pre-school registration for four year olds ${ }^{v}$ & $93.9 \%$ & $82.8 \%$ \\
\hline Rate of pre-school registration for five year olds ${ }^{\mathrm{VI}}$ & $97.5 \%$ & $94.5 \%$ \\
\hline Average class size in elementary school ${ }^{\text {VII }}$ & 24.54 & 28.81 \\
\hline $\begin{array}{l}\text { Rate of special needs children failing to get } \\
\text { appropriate medical services }\end{array}$ & $39 \%$ & $71 \%$ \\
\hline $\begin{array}{l}\text { Drop-out rate of elementary school students } \\
(2007-2008)^{\mathrm{IX}}\end{array}$ & $0.6 \%$ & $0.7 \%$ \\
\hline $\begin{array}{l}\text { Drop-out rate, students in } 9 \text { th-12th grades } \\
(2007-2008)^{\mathrm{X}}\end{array}$ & $13.5 \%$ & $21.3 \%$ \\
\hline $\begin{array}{l}\text { Rate of qualification for matriculation certificate } \\
\text { (of the type needed to receive university } \\
\text { admission or commensurate employment) }\end{array}$ & $75.9 \%$ & $30.8 \%$ \\
\hline
\end{tabular}

Source: Jabareen and Agbaria, 2011.

\section{International and National Examinations}

International Examination. Math is considered as the queen of sciences. Achievements in mathematics could reflect achievements in science. The Organisation for Economic Co-operation and Development (OECD) conducts a Programme for International Student Assessment (PISA). In Table 2, PISA achievements are shown for different groups. Achievements of Arabic Speaking Pupils Are Much Lower than those of Hebrew Speaking Pupils. 
Table 2. PISA International Examination Results between the Years 20032012

\begin{tabular}{|c|c|c|c|c|c|c|}
\hline & \multicolumn{3}{|c|}{ PISA Math } & \multicolumn{3}{c|}{ PISA Reading } \\
\cline { 2 - 7 } & Arabic & Hebrew & National & Arabic & Hebrew & National \\
\hline & & & & & & \\
\hline 2003 & 344 & 449 & 418 & 378 & 465 & 452 \\
\hline & & & & & & \\
\hline 2006 & 372 & 460 & 442 & 372 & 456 & 439 \\
\hline & & & & & & \\
\hline 2009 & 367 & 470 & 447 & 392 & 498 & 474 \\
\hline & & & & & & \\
\hline 2012 & & & 466 & & & 486 \\
\hline & & & & & & \\
\hline
\end{tabular}

Source: Wolf, 2014.

National Examination. Figure 4 shows lower achievements of Arabic speaking pupils compared to Hebrew speaking pupils, in all subjects considered. The figure shows the national examination scores at two periods of time, comparing the Arabic speaking and Hebrew speaking sectors. The scores show lower achievements of Arabic speaking pupils compared to the Hebrew speaking pupils.

Figure 4. "Meizav" Test Scores, $5^{\text {th }}$ and $8^{\text {th }}$ Grades 2005/6-2008/9

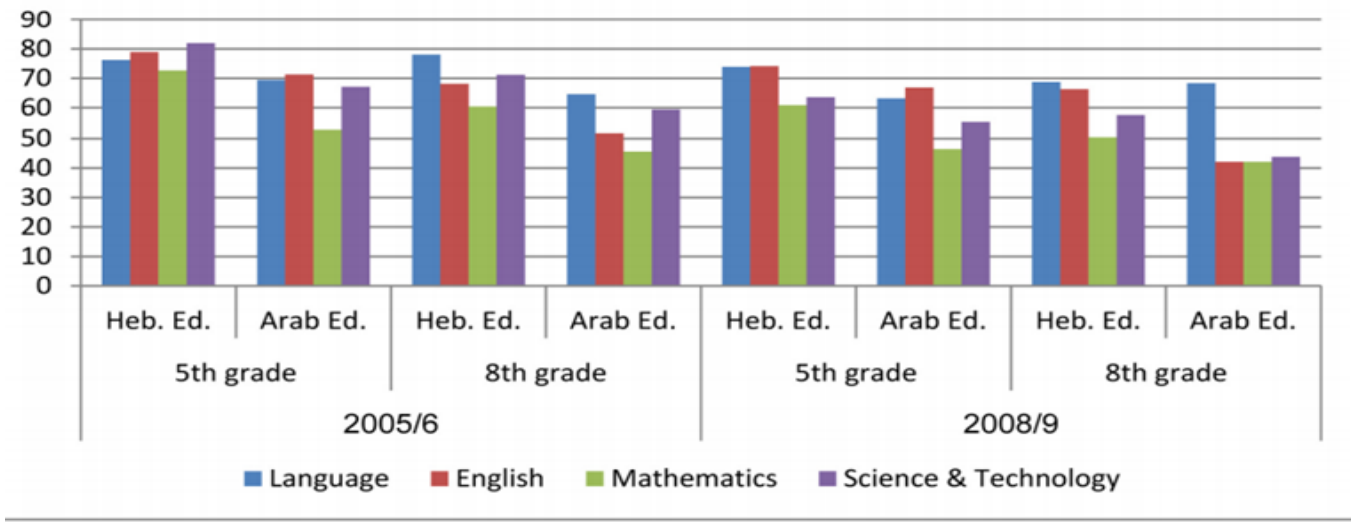

Source: Shaviv, Binstein, Stone, \& Fudem, 2013.

\section{Science Education at High School}

Recently Idit and Dana (2013) addressed the issue of science education at high schools in Israel. The study raises alarms for a worsening future considering the number of teachers, the number of hours of science subjects taught, and the low number of pupils choosing to study science-related subjects. The study stressed the need for action before it becomes too late, and also predicted a deficiency of high quality science teachers, engineers, and 
scientists in the workplace. Tables 3, 4, 5 and 6 highlight the status of the teachers, schools teaching science subjects, and pupils choosing science subjects (5 "bagrut" units).

Science Teachers. Table 3 shows the number of teachers who have taught at least one of three science subjects, indicating the number of teachers of each subject, and the percentage of the total number of teachers who provide instruction in each subject. Comparisons are made in 2002, 2007, and 2012.

Table 3. Distribution of Science Teachers in Israel in Specific Years (2002, 2007, 2012)

\begin{tabular}{|c|c|c|c|}
\hline & Biology & Physics & Chemistry \\
\hline $\mathbf{2 0 0 2}$ & $1,500(4 \%)$ & $872(2 \%)$ & $758(2 \%)$ \\
\hline $\mathbf{2 0 0 7}$ & $1,497(4 \%)$ & $830(2 \%)$ & $681(2 \%)$ \\
\hline $\mathbf{2 0 1 2}$ & $1,701(4 \%)$ & $1,071(3 \%)$ & $698(2 \%)$ \\
\hline
\end{tabular}

Source: Idit \& Dana, 2013.

Science Teachers per Sector. In Table 4 comparisons between the number of teachers in the different education systems are made in 2002 and 2012.

Table 4. The Table Shows the Number of Teachers per Sector

\begin{tabular}{|l|c|c|c|c|c|c|}
\hline \multirow{2}{*}{ Inspection } & \multicolumn{6}{|c|}{ Number of Teachers } \\
\cline { 2 - 7 } & \multicolumn{2}{|c|}{ Biology } & \multicolumn{2}{c|}{ Physics } & \multicolumn{2}{c|}{ Chemistry } \\
\cline { 2 - 7 } & $\mathbf{2 0 0 2}$ & $\mathbf{2 0 1 2}$ & $\mathbf{2 0 0 2}$ & $\mathbf{2 0 1 2}$ & $\mathbf{2 0 0 2}$ & $\mathbf{2 0 1 2}$ \\
\hline Hebrew speaking non-religious & 971 & 934 & 543 & 589 & 472 & 352 \\
\hline Jewish religious & 298 & 367 & 147 & 197 & 91 & 61 \\
\hline Arabic speaking & 231 & 400 & 182 & 241 & 195 & 285 \\
\hline
\end{tabular}

Source: Idit \& Dana, 2013.

Number of Students. In Table 5 comparisons of the achievements of students (all sectors) in biology, physics and chemistry are made between the years 2006 and 2009.

Table 5. Percentage of Students who Studied Science and Took Matriculation Tests in Specific Science Subjects (5 "Bagrut" Units)

\begin{tabular}{|c|c|c|c|c|c|c|}
\hline \multirow{2}{*}{ All sectors } & \multicolumn{5}{|c|}{ Percentage of Students - 5 "Bagrut" Units } \\
\cline { 2 - 7 } & \multicolumn{3}{|c|}{ Biology } & \multicolumn{2}{c|}{ Physics } & \multicolumn{2}{c|}{ Chemistry } \\
\cline { 2 - 7 } & $\mathbf{2 0 0 6}$ & $\mathbf{2 0 0 9}$ & $\mathbf{2 0 0 6}$ & $\mathbf{2 0 0 9}$ & $\mathbf{2 0 0 6}$ & $\mathbf{2 0 0 9}$ \\
\hline $\begin{array}{c}\text { Taking Bagrut } \\
\text { examination }\end{array}$ & 15 & 19 & 10 & 10.50 & 11.80 & 352 \\
\hline
\end{tabular}

Source: Idit \& Dana, 2013.

Percentage of High Schools Teaching Science. In Table 6 comparisons between the percentage of high schools teaching science in the different education systems are made in 1996 and 2012. 
Table 6. Percentage of High Schools (with Jewish Religious Schools Identified as a Separate Sector) that Teach Science Subjects

\begin{tabular}{|l|c|c|c|c|c|c|}
\hline \multirow{3}{*}{ Inspection } & \multicolumn{3}{|c|}{ Percentage of Schools Teaching Science } \\
\cline { 2 - 7 } & \multicolumn{2}{|c|}{ Biology } & \multicolumn{2}{c|}{ Physics } & \multicolumn{2}{c|}{ Chemistry } \\
\cline { 2 - 7 } & $\mathbf{1 9 9 6}$ & $\mathbf{2 0 1 2}$ & $\mathbf{1 9 9 6}$ & $\mathbf{2 0 1 2}$ & $\mathbf{1 9 9 6}$ & $\mathbf{2 0 1 2}$ \\
\hline Hebrew speaking non-religious & 63.81 & 70.54 & 65.5 & 67.9 & 61.3 & 51.2 \\
\hline Jewish religious & 63.29 & 69.6 & 52.7 & 53.5 & 43 & 15.7 \\
\hline Arabic speaking & 70.8 & 73.9 & 72.6 & 69.1 & 72.6 & 71.5 \\
\hline
\end{tabular}

Source: Idit \& Dana, 2013.

\section{Undergraduate Studies}

Figure 5 shows a distribution of students in undergraduate studies. The minority group (Arabic speaking students) is represented in smaller figures compared to the majority group (Hebrew speaking students). The figure shows lower numbers in science and technology subjects of the minority group.

Figure 5. Distribution of the Majority Group and Minority Group in Undergraduate Studies

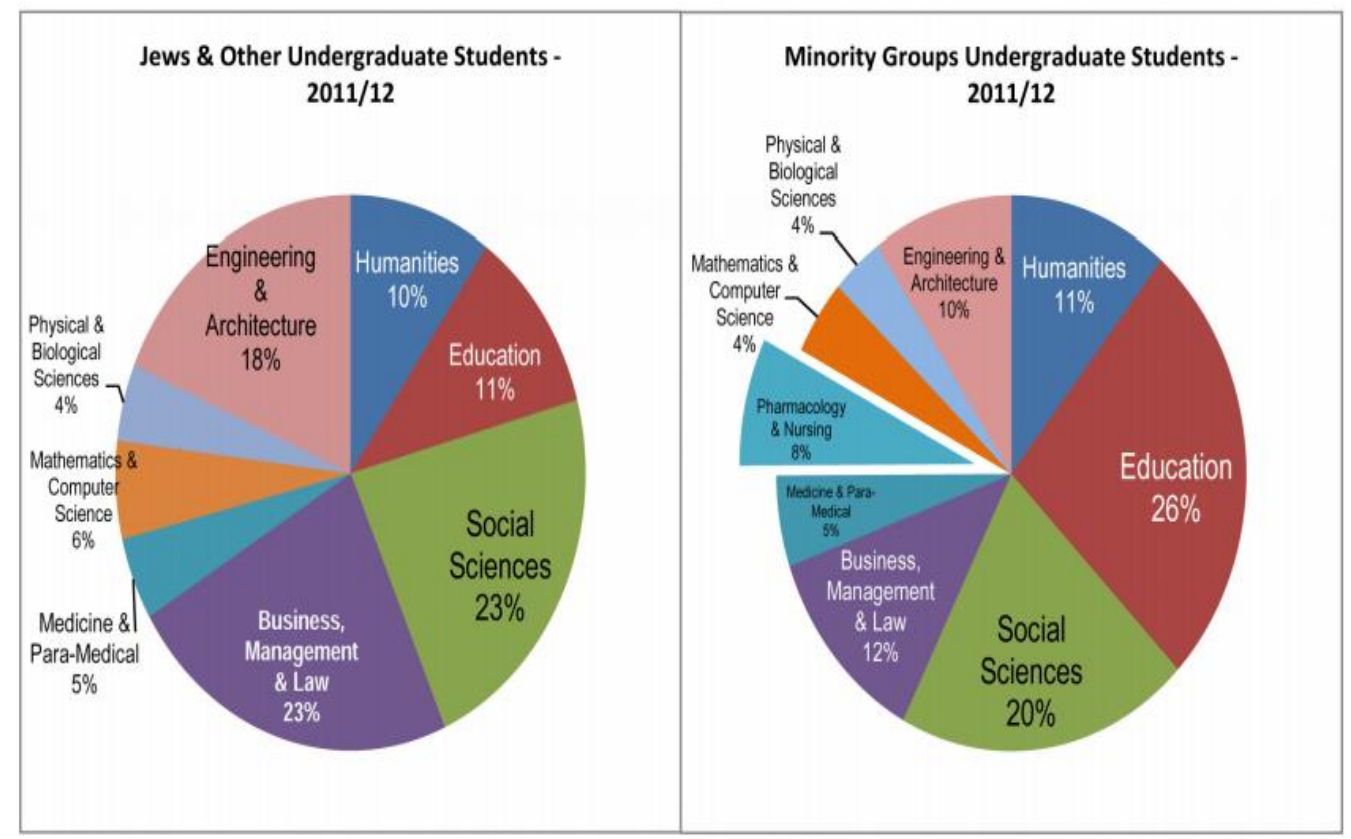

Source: Shaviv, Binstein, Stone, \& Fudem, 2013. 


\section{Summary of Findings at High Schools}

\section{Number of Teachers}

Based on Tables 3 and 4, above, the number of teachers increased in all subjects in the Arabic speaking education system; in the non-religious Hebrew speaking sector the number of physics teachers increased but the numbers of biology and chemistry teachers decreased. In the religious Jewish sector the number of chemistry teachers decreased while the numbers of physics and biology teachers increased. It is noticeably clear that the number of biology teachers in the Arabic speaking sector attained the highest increase.

It was predicted in Idit and Dana (2013) that in the future the number of high quality science teachers will decrease and that there will be a deficit in their numbers. One possible explanation of the expected deficiency, as was described in the study, is the low status of teachers (job with low income, hard work) in Israel, with new teachers leaving the system after gaining a few years of experience.

\section{Number of Students}

From Table 5 it is clear that the number of students who study science subjects (5 "bagrut" units) is relatively low. These low numbers are reflected in their participation in post-high school undergraduate and graduate studies, especially among the Arabic speaking students.

\section{Science Subjects and Number of Schools}

Table 6 shows that the number of Arabic speaking schools that teach science subjects has increased over the years.

It is important to note, however, that while the situation seems to be improving, the absolute numbers of Arabic speaking students who study science subjects are low. After the recommendations of "Tomorrow 98" that were reported in the report of the Supreme Committee for Scientific and Technological Education, Ministry of Education (Harari, 1992), it was decided to teach six hours of science and technology as a single subject. The unfortunate reality, however, indicated that schools ended up teaching only four hours (Idit \& Dana, 2013), almost half of which were dedicated to biology. This might explain the increase in the number of students who study biology in high school.

\section{Student Achievements and Attitudes}

It was noted by Idit and Dana, 2013that the percentage (relative number) of students in all subjects with 5 "bagrut" units is high (97\% and higher) and half of those students attain grades of 85 (score) and above.

As was noted earlier, the achievements made in international and national 
examinations are low, particularly when compared to the average of OECD countries. In addition, the achievements of Arabic speaking students are much lower than the achievements of Hebrew speaking students.

In the education professional sector, the number of women in the science and technology and high-tech sector is lower than the number of men (Idit \& Dana, 2013).

According to the International Association for the Evaluation of Educational Achievement (Idit \& Dana, 2013), the organization that administers the Trends in the International Mathematics and Science Study assessments, Hebrew speaking students showed a lower preference to engage in science subjects than did the international mean. Arabic speaking students expressed greater interest in studying sciences than did the Hebrew speaking students. This observation is supported with the results of the PISA examination, Israeli students in general show low motivation to study science subjects.

\section{Factors that Affect Achievements}

\section{Ethnic Origins}

According to Dan (2014), Israeli Arabs and Haredim constitute, roughly half of the population of Israel. Due to their religions and believes, the high number of family members and low income, education is not at high priority for them. This affects the overall achievements of Israeli students. Although the percentage of enrolments have increased in the last thirteen years (between 2000-2013), the educational achievements of these groups are below the achievements of students in developing countries. As was emphasized in Dan (2014): "Children receiving an education below developing world levels will have major problems contending with the needs of a First World economywith all of the obvious economic implications that this entails".

\section{Discipline}

How do disciplined/undisciplined students affect educational achievements? What are the reasons for undisciplined behavior? As was reported in Dan (2014), disciplined students gained approximately ten grades more than undisciplined peers. Thus undisciplined behavior, negatively affects the students achievements. One of the major reasons that might motivate undisciplined behavior is the unfair treatment of teachers (Dan, 2014).

\section{Institutional Barriers}

Contrary to the claims that were reported by Dan (2014) regarding cultural and ethnic reasons for low achievements of Israeli Arab students, the main 
reason for low enrollment to education systems are, "the institutional obstacles placed before them, the neglect in elementary and high school education, and the structural barriers they face. These barriers are clearly evident in an examination of the percentage accepted to the universities relative to their numbers; according to age groupings, in the mid-1980s Arabic speakers were $22.7 \%$ of 18 -year-olds, but only $7.4 \%$ of them were accepted to universities" (Ali, 2013).

\section{Socio-economic Stumbling Blocks}

According to Wolf and Breit (2012) in Israel, as elsewhere, factors external to the education system have a strong impact on learning. Israel has a large gap in income between the rich and the poor. This gap is wider than that in nearly all OECD countries, although it is comparable to similar findings in the US. In 2008, 32\% of all Israeli families, many of them ultra-orthodox or Arab, had a gross income below the poverty line (Wolf \& Breit, 2012).

\section{Factors Found in International Studies}

Several factors might affect the process of teaching and learning. Among these are: the role of student motivation in learning and teaching contexts (Pintrich, 2003); the importance of starting small (Elman, 1993); Learning styles (Pashler, McDaniel, Rohrer, \& Bjork, 2009); Motivational and selfregulated learning components of classroom academic performance (Pintrich \& De Groot, 1990); effects of teaching strategies on student achievement in science in the United States (Schroeder, Scott, Tolson, Huang, \& Lee, 2007); The impact of school, family, and community-connections on student achievement (Henderson \& Mapp, 2002); Effects of teacher professional development on gains in student achievement (Blank \& de las Alas, 2009); Social-Psychological Interventions in Education (Yeager \& Walton, 2011); Parental involvement in middle school (Hill, \& Tyson, 2009); The Impact of School Environments (Higgins, Hall, Wall, Woolner, \& McCaughey, 2005); the benefits of school gardening (Blair, 2009); frequency of hands-on experience and science achievement (Stohr- Hunt, 1996); Effects of frequent classroom testing (Bangert- Drowns, Kulik, \& Kulik, 1991); the importance of the purpose of science experiments (Hart, Mulhall, Berry, Loughran, \& Gunstone, 2000); Sources of science self-efficacy beliefs of middle school students (Britner \& Pajares, 2006); Class size and student achievement (Ehrenberg, Brewer, Gamoran, \& Willms, 2001); the laboratory in science education and foundations for the $21^{\text {st }}$ century (Hofstein \& Lunetta, 2004); Project based learning at the kindergarten: Solar ovens (Mahmoud \& Huriya, 2011) and solar buildings (Huleihi, Huleihil, \& Mazor, 2013).

Figure 6 is a diagram of different factors that affect the classroom climate. 
Figure 6. Factors that Affect Classroom Climate

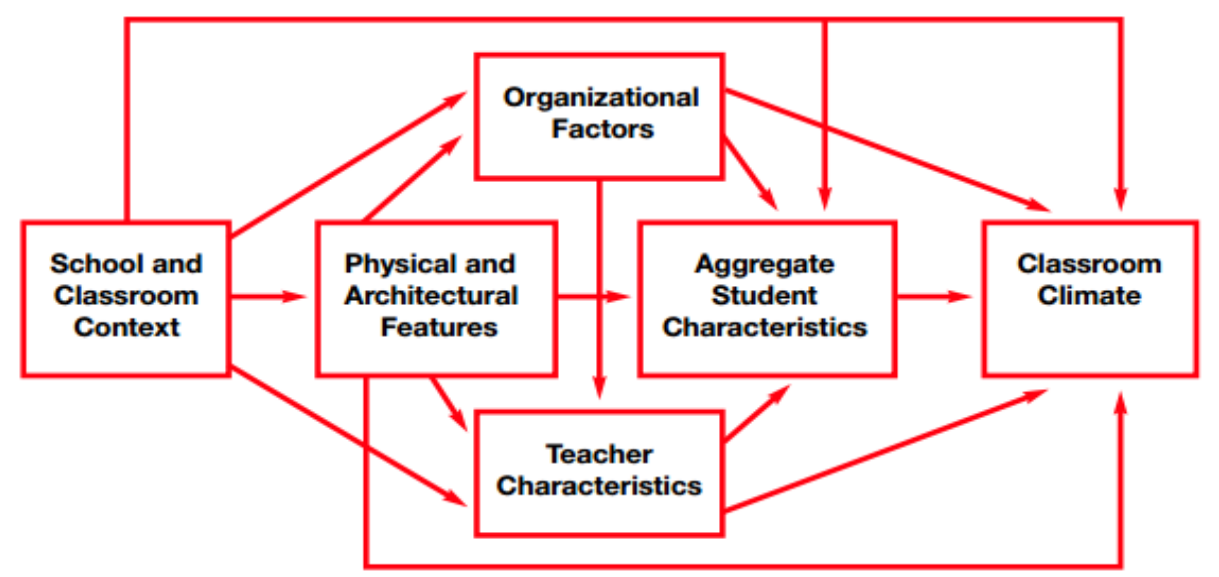

Source: Higgins, Hall, Wall, Woolner, \& McCaughey, 2005.

As can be seen from the figure, the education system encounters many factors or subsystems that should interact optimally towards achieving desired goals.

\section{Results}

The main findings are: 1 . The average nationwide scores on international examinations- excluding ultra-orthodox Jewish (Haredi) children-are among the lowest in the developed world; 2. The education provided to Israeli Arabic speaking children yields achievements in math, science, and reading that are not only lower than the achievements of their Israeli Hebrew speaking peers, but rather below those of the children in developing world countries such as Jordan, Tunisia, and Malaysia; 3 . The achievements of Israeli Arabic speaking students at the high school level do show relative local improvements; 4 . The number (absolute and percentage) of Arabic speaking students at the university level is much lower than the number of Hebrew speaking students; 5. In general, the higher the level one might examine, the lower the representation of Arabic speaking members.

\section{Discussion}

It is evident that gaps exist between the achievement of Israeli Arab students and Israeli Jewish students. What are the reasons or variables behind these gaps?

One of the main reasons is discrimination. The Israeli society is diverse, there are many different groups: the immigrant group with western origins (Ashkenazi), the immigrant group with middle- eastern origins (Mizrahi), the Israeli-born Jews (Sabra), and minority non-Jewish group. The population 
could be classified differently: Orthodox versus secular), men versus women, poor versus rich and so on (Haberfeld \& Cohen, 2007). According to Hesketh, Bishara, Rosenberg, and Zaher (2011), "Arab citizens of Israel, a national, nonimmigrant minority living in its historical homeland today comprise approximately $20 \%$ of the total population of Israel, numbering almost 1.3 million people".

The Israeli Arab minority suffered from discrimination and poor treatment of the Israeli government in every aspect of life and affects every aspect of the education system (Human Rights Watch, 2001; Haberfeld \& Cohen, 2007; Coursen-Neff, 2004). Specifically, discrimination is evident in the educational system (Arar, 2012): "allocation of resources, including physical infrastructure and classrooms, teaching hours, and enrichment hours, the Arab minority in Israel and its culture are not officially recognized, and its leadership is excluded from education policy-making"; fewer unique programs, bad physical conditions and lack of study aids; Also very important is the preparation of Arab teachers "The Arab education system receives inferior allocations for training, supervision, nature, and art lessons" (Golan-Agnon, 2006).

The less investment in training and preparing Arab teachers will lead to lower numbers of qualified Arab teachers and a few of them will have the opportunity to obtain an academic degree (Human Rights Watch, 2001). Crowded and larger classes with smaller room and space, dictate bigger challenges for Arab teachers.

As was reported in Haberfeld and Cohen (2007), it was found that discrimination is not the main reason for low achievements and lower income among the different ethnic groups studied (Mizrahi men, Arab men, Ashkenazi women, and Mizrahi women), but rather, productivity related variables could explain the existing earning gaps.

More than that, factors and variables that might contribute to success are: "general well-being, economic standard of living, parents' educational background, and investment in the child". Based on data of the Israel Central Bureau of Statistics, the rate of Jewish students in Israel who are eligible for a matriculation certificate is $60 \%, 21 \%$ points higher than the rate of non-Jewish students. Within the non-Jewish sector, there are large differences in the rates of eligibility: $63 \%$ of the Christian students become eligible, $29 \%$ points more than the rate among Moslems and the other smaller communities in Israel (Dahan, Dvir, Mironichev, \& Shye, 2003).

The educational challenge of serving a schools population in a divided system that is in its majority Haredi and Arab, to say nothing of the political, social, and economic implications of a future a majority of Haredi and Arab population, are daunting. In terms of the economy, there will likely be increased numbers of young adult Haredim who are neither prepared nor willing to enter the labor market, thus requiring the rest of society to subsidize ever-larger numbers of Haredi families. While Arabs are increasingly completing secondary education and entering higher education, inadequate technical and scientific knowledge, inadequate knowledge of Hebrew by Arabs, and discrimination in the labor market will make it difficult to fully 
utilize the Arab labor force, with negative impacts on the prospects for increased productivity of Israel's labor force as a whole (Wolf \& Breit, 2012).

\section{Summary and Conclusions}

In this review, the status of science education in Arabic speaking schools was considered. Although the focus was on high schools, for the sake of drawing a better picture, achievements in earlier school grades, as well as studies after high school, were also considered.

We found that the overall achievements of Arabic speaking students were low in all stages of the education system. At the high school and higher education levels, this was expressed by the low number of students who chose science and technology subjects, and at the middle school level this was expressed by the results of international and national examinations and assessments. The reduction of the science and technology teaching hours in middle schools affected the decision and choice of the students who continued to high school. This is a probable explanation of the low number of students who studied science subjects. It was noticed that biology garnered the biggest share of interest and participation at middle school and high school levels.

In conclusion, the reasons for the low achievement levels of Arabic speaking students in general, and particularly in the science subjects, vary from low socioeconomic levels, institutional barriers, low teacher quality, discipline problems, and issues of motivation and self-efficacy of the students, among the many factors described in the review.

\section{Recommendations}

As one can see, the system of teaching and learning is highly nonlinear and multidimensional, with multi-objective functions.

Intuitively, it is possible to classify these into two major parts: internal factors and external factors.

Education involves many processes that must develop inside the learner. Some of the major questions are: how much time do we have, when do we start education, and what budget is needed? How many parties are involved in the process and how efficiently do they interact? Good answers to these questions should lead to greater success in the achievements of the students.

It is important to highlight that one of the most important objective functions is student achievement. Success is basically in the hands of the learner himself. Should he be creative, independent, and take responsibility?

It is important to maximize all the factors leading to student success: empowering the teachers, supplying basic conditions and needs, investing in good laboratories and a well-designed curriculum. But more than that, the learner himself has to take responsibility for his studies and continue to seek 
success.

Things that are essentially external and that might direct the students towards success are:

1. Collaboration between Israeli parties should lead to better results and achievements. It is a good idea to learn from successful models, either locally or internationally.

2. Teaching science should start as early as possible (at home, even before nursery school begins). Examples of project based learning (PBL) at the kindergarten level are given in 33-34.

3. Libraries for children should be enriched with science stories, at home and school.

4. Parents should be important partners and be involved in the process of education, especially when the children are young, until they become independent and responsible.

5. Plan to achieve the stated goals of the Ministry of Education, which are to prepare the citizens of the future, a student who is oriented toward science and technology, independent, creative, with the abilities to think at higher levels, demonstrating powers of analysis, synthesis, and assessment. Thought and effort should be spent seeking the best practices such as trust, confidence, respect, and responsibility.

6. Environment of the student, both at home and at school, should be rich in stimulation, to encourage him, among other things, to search, find, see, construct, experiment, imagine, grasp, and make.

7. The characteristics shown in Figure 7 should be encouraged and developed in the learner. These characteristics might increase success among the students. 
Figure 7. A Star Representation of Important Characteristics to be Encouraged and Developed in the Learners

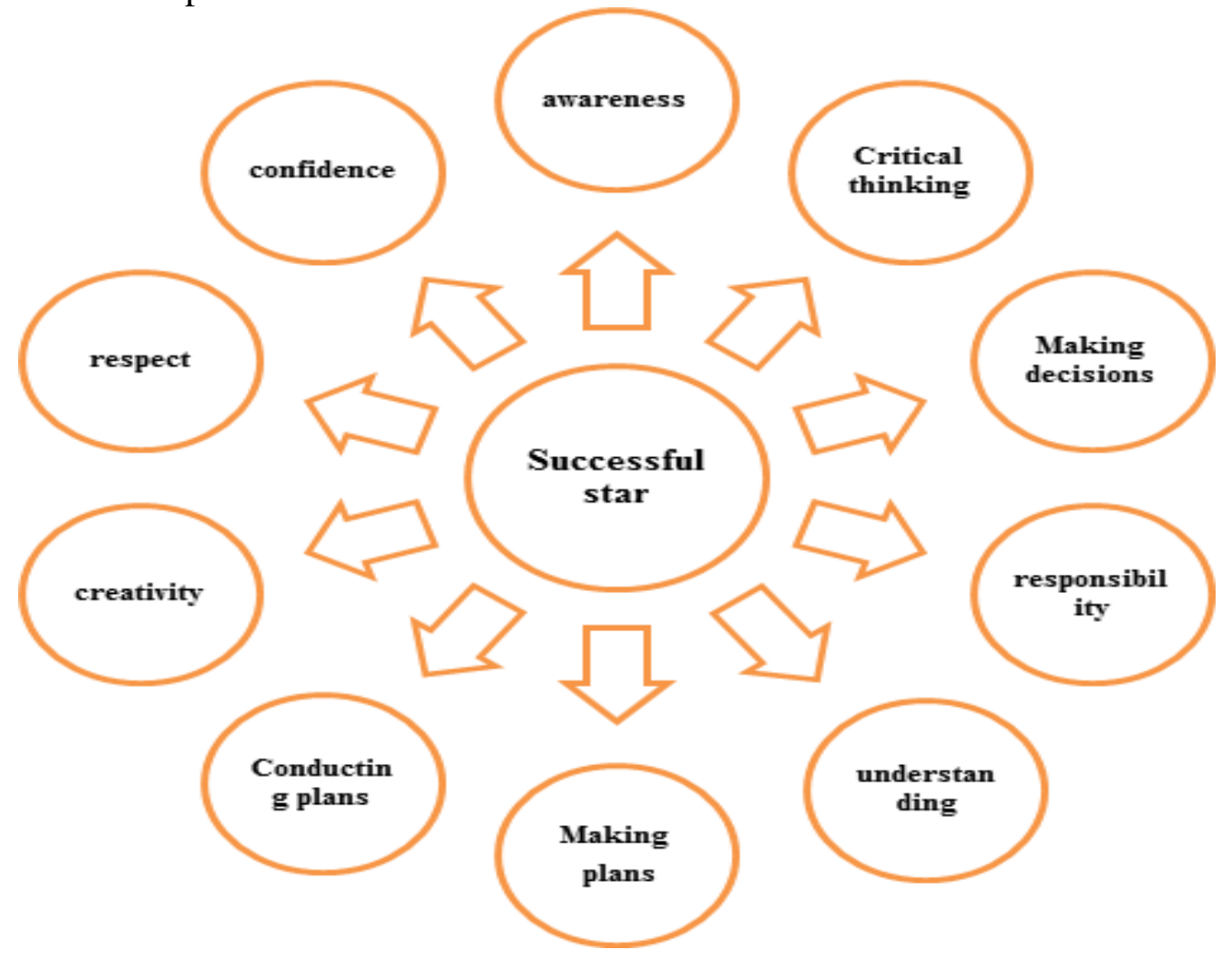

The following subsections describe two models of action aimed toward developing successful education processes:

- Three-step model (triangular model): The triangular model is constructed in three steps: increasing awareness; plotting a solution or a plan of action; and giving responsibility.

- Four-step model (problem solving-Polya type of model).

The four-step Polya-type model includes the following: understanding the problem; devising a plan; conducting the plan; and checking the entire process. The four steps could be stated as follows: understanding the problem; formulating the problem in mathematical language; solving the mathematical problem; and returning back to the real world by checking the solution.

\section{References}

Ali, N. (2013). Representation of Arab citizens in the institutions of higher education in Israel. Jerusalem, Haifa: Pears foundation and Sikkuy: 1-53. Retrieved from http://bit.ly/1Rxw8Et.

Arar, K. (2012). Israeli education policy since 1948 and the state of Arab education in 
Israel. Italian Journal of Sociology of Education, 1, 113-145.

Bangert- Drowns, R., Kulik, J., \& Kulik, C.-L. (1991). Effects of frequent classroom testing. The Journal of Educational Research, 85(2), 89-99.

Blair, D. (2009). The child in the garden: An evaluative review of the benefits of school gardening. The Journal of Environmental Education, 40(2), 15-38.

Blank, R. K. \& de las Alas, N. (2009). Effects of teacher professional development on gains in student achievement. Washington, DC: Council of Chief State School Officers, Washington, DC, 27.

Britner, S. L. \& Pajares, F. (2006). Sources of science self-efficacy beliefs of middle school students. Journal of Research in Science Teaching, 43(5), 485-499.

Coursen-Neff, Z. (2004). Discrimination against Palestinian Arab children in the Israeli educational system. Journal of International Law and Politics, 36 (749), 101-162.

Dahan, M., Dvir, E., Mironichev, N., \& Shye, S. (2003). Have the gaps in education narrowed? On factors determining eligibility for the Israeli matriculation certificate. Israel Economic Review 2, 37-69.

Dan, B. D. (2014). A Picture of the nation Israel's society and economy in figures 2014. Jerusalem: Taub Center for Social Policy Studies in Israel Jerusalem, 1-92.

Elman, J. L. (1993). Learning and development in neural networks: the importance of starting small. Cognition, 48 (71).-99.

Ehrenberg, R. G., Brewer, D. J., Gamoran, A., \& Willms, D. J. (2001). Class size and student achievement. Psychological science in the public interest, 2(1), 1-30.

Golan-Agnon, D. (2006). Separate but not equal: Discrimination against Palestinian Arab students in Israel. American Behavioral Scientist 49(8), 1075-1084.

Haberfeld, Y., \& Cohen, Y. (2007). Gender, ethnic, and national earnings gaps in Israel: The role of rising inequality. Social Science Research 36, 654-672.

Harari, H., (1992). Tomorrow 98. Report of the Supreme Committee for Scientific and Technological Education. Ministry of Education.

Hart, C., Mulhall, P., Berry, A., Loughran, J., \& Gunstone, R. (2000). What is the purpose of this experiment? Or can students learn something from doing experiments?. Journal of Research in Science Teaching, 37(7), 655 - 675.

Henderson, A. T. \& Mapp, K. L. (2002). A new wave of evidence: The impact of school, family, and community-connections on student achievement. Texas: Southwest Educational Development Laboratory (SEDL), 7-8

Hesketh, K., Bishara, S., Rosenberg, R., \& Zaher, S. (2011). The Inequality Report: The Palestinian Arab Minority in Israel. Israel: ADALAH, The legal center for Arab minority rights in Israel, 1-73. Retrieved from http://bit.ly/1Oqi9Ck

Higgins, S., Hall, E., Wall, K., Woolner, P., \& McCaughey, C. (2005). The Impact of School Environments: A literature review. The Centre for Learning and Teaching School of Education, Communication and Language Science, University of Newcastle,1-47, Retrieved from http://bit.ly/1NtPY4c.

Hill, N. E. \& Tyson, D. F. (2009). Parental involvement in middle school: A metaanalytic assessment of the strategies that promote achievement. Developmental Psychology, American Psychological Association, 45(3), 740-763.

Hofstein, A., \& Lunetta, V.N. (2004). The laboratory in science education: foundations for the twenty-first century. Science Education, 88(1), 28-54.

Huleihi, M., \& Huleihil' H. (2011). Bringing green energy to Arab schools in the Negev, south of Israel: Solar ovens. Proceedings of the Global Conference on Global Warming 2011, 11-24 July, Lisbon, Portugal, 1-5.

Huleihi, M., Huleihil, H., \& Mazor, G. (2013). Several aspects of solar buildings towards sustainability: the massive wall, green energy, and early environmental 
education. Latin-American Journal of Physics Education, 7(2), 201-208.

Human Rights Watch. (2001). Second Class: Discrimination against PalestinianArab Children in Israel's Schools. USA: Author. Retrieved from http://bit.ly/1Rx KYLa.

Idit M. I. \& Dana R. (2013). Science teaching in Israel: Trends, challenges and change views. Henrietta Szold Institute, 1-38. (in Hebrew).

Jabareen, Y., \& Agbaria, A. (2011). Education on Hold: Government Policy and Civil Society Initiatives to advance Arab Education in Israel. Nazareth: Dirasat, Arab Center for Law and Policy, 1-26.

Pashler, H., McDaniel, M., Rohrer, D. \& Bjork, R. (2009). Learning styles: concepts and evidence, A Journal of the Association of Psychological Science-APS, 9(3), 105-119.

Pintrich, P. R. (2003). A motivational science perspective on the role of student motivation in learning and teaching contexts. Journal of Educational Psychology, 95 (4), 667-686.

Pintrich, P. R. \& De Groot, E. (1990). Motivational and self-regulated learning components of classroom academic performance. Journal of Educational Psychology, 82(1), 33-40.

Schroeder, C. M., Scott, T. P., Tolson, H.T., Huang, T.Y., \& Lee, Y.-H. (2007). A meta-analysis of national research: effects of teaching strategies on student achievement in science in the United States. Journal of Research in Science Teaching, 44(10), 1436-1460.

Shaviv, M., Binstein, N., Stone, A., \& Fudem, O. (2013). Pluralism and equal opportunity in higher education expanding access for Arabs, Druze and Circassians in Israel. PBC - Planning and Budgeting Committee of the Council for Higher Education, 11-77. Retrieved from http://bit.ly/1WxNfMJ.

Stohr- Hunt, P. (1996). An analysis of frequency of hands-on experience and science achievement. Journal of Research in Science Teaching, 33(1), 101-109.

Wolf, L. (2014). Learning assessments in Israeli's schools: Beyond controversy and towards best practice. Washington DC: GIIS-The Gildenhorn Institute for Israel Studies, University of Maryland: 1-15.

Wolf, L., \& Breit, E. (2012). Education in Israel: The challenges ahead. Washington DC: GIIS-The Gildenhorn Institute for Israel Studies, University of Maryland: 128.

Yeager, D.S. \& Walton, G. M. (2011). Social-Psychological Interventions in Education: They're Not Magic. Review of Educational Research, 81(2), 267-301. 
